\title{
Tracing the Boundaries between Disability and Sickness in the European Union: Squaring the Circle?
}

\author{
Silvia Favalli \\ PhD candidate, Law School, University of Pavia, Pavia, Italy \\ Delia Ferri \\ Attorney (Verona Bar); Lecturer in Law, Department of Law, Maynooth \\ University, Maynooth, Co. Kildare, Ireland
}

\begin{abstract}
In recent years the European Union (EU) has sought to develop a far-reaching policy regarding persons with disabilities. However, to date, EU non-discrimination legislation does not provide any clear legal definition of what constitutes a disability. The Court of Justice of the European Union (CJEU) has attempted to fill this gap and, in several decisions, has elaborated on the concept of disability and its meaning under EU law. The CJEU, with reference to the application of the Employment Equality Directive, has explained the notion of disability mainly by comparing and contrasting it to the concept of sickness. Against this background, this article critically discusses recent case law and attempts to highlight that, even though the Court has firmly embraced the social model of disability envisaged by the UN Convention on the Rights of Persons with Disabilities, the boundaries between the concepts of sickness and disability remain blurred.
\end{abstract}

\footnotetext{
* This article is the product of a joint reflection. However, Sections 1, 2 and 6 have been written by Delia Ferri and Sections 3, 4 and 5 have been written by Silvia Favalli, while Section 7 has been written jointly. Our special thanks go to Mr. Charles O'Sullivan and Dr Fergus Ryan for their helpful remarks and comments on an earlier draft. The usual disclaimer applies.
} 


\section{Keywords}

disability - sickness - discrimination on the ground of disability - Court of Justice of the European Union (CJEU) - Employment Equality Directive - United Nations Convention on the Rights of Persons with Disabilities (CRPD) - social model of disability

\section{Introduction}

Despite the recent expansion of disability studies and the great surge of interest in 'disability' across various strands of legal literature, as yet, there is no shared understanding of what constitutes a disability in a normative sense. In the European context, the lack of uniformity in scholarship mirrors a similar lack of a clear and univocal legal definition of disability in European Union (EU) law, as well as the fact that Member States define disability in different ways under their own national legal framework. ${ }^{1}$ In other words, although the EU has developed a far-reaching disability policy, ${ }^{2}$ it has implicitly left the uneasy task of identifying the criteria to define a 'person with disabilities' to national legislation. ${ }^{3}$

1 M. Leonardi, 'Defining disability - Re-defining policy', International Journal of Integrated Care (2009), 22 June 2009, http://www.ncbi.nlm.nih.gov/pmc/articles/PMC2707551/, retrieved 14 April 2015.

2 Amongst others, L. Waddington, From Rome to Nice in a Wheelchair. The Development of a European Disability Policy (Maastricht: Europa Law Publishing, 2006); L. Waddington, 'The European Union and the United Nations Convention on the Rights of Persons with Disabilities: A Story of Exclusive and Shared Competences', Maastricht Journal of European and Comparative Law 18(4) (2011) 431-453; D. Hosking, 'Staying the Course: The European Disability Strategy 2010-2020', in: L. Waddington, G. Quinn and E. Flynn (eds.), European Yearbook of Disability Law 4(2013) pp. 73-99; D. Ferri, 'Is there a 'Cultural Dimension' of EU Disability Policy? New Perspectives after the Accession to the UN Convention on the Rights of Persons with Disabilities', in: L. Zagato, D. Costantini, F. Perocco (eds.), Trasformazioni e crisi della cittadinanza sociale (Venice: Venice University Press, 2014) pp. 241-268.

3 Notable is the exception of State aid law: see Commission Regulation (EU) No 651/2014 of 17 June 2014 declaring certain categories of aid compatible with the internal market in application of Articles 107 and 108 of the Treaty Text with EEA relevance [2014] OJ L 187/1. This regulation (Art. 2) refers to 'worker with disabilities' as those who are recognized 'worker with disabilities under national law'; or 'has long-term physical, mental, intellectual or sensory impairment(s) which, in interaction with various barriers, may hinder their full and effective participation in a work environment on an equal basis with other workers'. The 
Current EU legislation includes disability-related provisions in various areas, such as transport, ${ }^{4}$ lifts, ${ }^{5}$ public procurement, ${ }^{6}$ State aid ${ }^{7}$ and electronic communications networks and services. ${ }^{8}$ However, the quest and need for a uniform definition of disability across the EU has only emerged prominently in the non-discrimination field, in particular in relation to Directive 2000/78/ EC of 27 November 2000 establishing a general framework for equal treatment in employment and occupation ('Employment Equality Directive'). ${ }^{9}$ At first sight, it might be surprising that the discussion has been confined to the non-discrimination field and did not extend to other areas, in stark contrast with the general need for the uniform application of EU law. However, this is due to the fact that the definition of the ground of disability is of paramount importance to determine the actual scope of the Employment Equality Directive ratione personae, and to define the limits of the non-discrimination protection in the EU legal order. In fact, only a uniform definition of disability

second alinea of this Article is clearly inspired by the un Convention on the Rights of Persons with Disabilities (see infra Section 2).

4 See, e.g., Regulation (EC) No. 1899/2006 of the European Parliament and of the Council of 12 December 2006 amending Council Regulation (EEC) No. 3922/91 on the harmonization of technical requirements and administrative procedures in the field of civil aviation, [2006] OJ L 377/1; Directive 2006/87/EC of the European Parliament and of the Council of 12 December 2006 laying down technical requirements for inland waterway vessels and repealing Council Directive 82/714/ EEC, [2006] OJ L 389/1; Commission Regulation (EC) No. 8/2008 of 11 December 2007 amending Council Regulation (EEC) No. 3922/91 as regards common technical requirements and administrative procedures applicable to commercial transportation by airplane, [2008] OJ L 10/1; Regulation (EC) No. 1370/2007 of the European Parliament and of the Council of 23 October 2007 on public passenger transport services by rail and by road and repealing Council Regulations (EEC) Nos. 1191/69 and 1107/70, [2007] OJ L 315/1; Regulation (EC) No. 1371/2007 of the European Parliament and of the Council of 23 October 2007 on rail passengers' rights and obligations, [2007] OJ L 315/14; Regulation (EC) No. 1107/2006 of the European Parliament and of the Council of 5 July 2006 concerning the rights of disabled persons and persons with reduced mobility when travelling by air, [2006] OJ L 204/1.

5 Directive 95/16/EC on the approximation of the laws of the Member States relating to lifts, [1995] OJ L 213/1.

6 Directive 2004/17/EC coordinating the procurement procedures of entities operating in the water, energy, transport and postal services sectors, [2004] OJ L 134/1; Directive 2004/18/EC on the coordination of procedures for the award of public works contracts, public supply contracts and public service contracts, [2004] OJ L 134/114.

7 Supra note 3.

8 Directive 2002/22/EC on universal service and users' rights relating to electronic communications networks and services (Universal Service Directive), [2002] OJ L 108/51.

9 [2000] OJ L 303/16. 
allows Member States to adopt a fair basis for differential treatment ${ }^{10}$ consistent across the EU. The importance of defining what constitutes a disability in the non-discrimination field has been perceived since the adoption of the Employment Equality Directive. Acknowledging the potential risk of an inconsistent implementation of the Directive, the European Commission itself, in 2002, launched and financed a research project on 'Definitions of Disability'. The project, which asked for a comparative analysis of the definitions of disability used in cash benefits and employment services provisions across the EU, highlighted that there are definitions which differ from a Member States to another.11

The Court of Justice of the European Union (CJEU) has been called upon several times to provide a consistent interpretation of the meaning of disability, as a ground of discrimination, on the assumption that EU provisions must be given an autonomous and uniform interpretation throughout the Union. In many cases, the Court has tried to define disability by comparing and contrasting this concept with that of sickness, highlighting the differences in the levels of protection against discrimination provided by EU law. CJEU case law has been largely boosted by the EU accession to the UN Convention on the Rights of Persons with Disability (CRPD or simply 'the Convention'), ${ }^{12}$ which has become a clear point of reference in the reasoning of the European judges. These recent attempts of the CJEU to clarify the meaning of disability have boosted the debate among legal scholars. It might be argued that defining disability is immaterial or irrelevant to legal research. As several academics contend, ${ }^{13}$ however, the way in which disability is conceived has a decisive

10 D. Mabbett, 'Some are More Equal Than Others: Definitions of Disability in Social Policy and Discrimination Law in Europe', Journal of Social Policy 34 (2005) 215-233, p. 216. In particular, Mabbet argues that 'it may not be possible to promote sufficient substantive equality without treating some people differently on grounds of disability. If so, it is necessary to have an idea of what constitutes a fair basis for 'differential treatment'.

11 Study reported by D. Mabbett, 'Definitions of Disability in Europe. A Comparative Analysis', Final Report 13 December 2002, a study prepared by Brunel University, UK (European Commission), http://www.hiproweb.org/fileadmin/cdroms/Kit_Formation_Services/ documents/Additional/B-Social_policy_and_Disability/B-3_Definition_of_disability_in_ Europe_Brunel_University_2002.pdf, retrieved 14 April 2015.

12 Council Decision 2010/48/EC, [2010] OJ L 23/35.

13 Ex pluribus P. Auvergnon, 'Approche juridique du handicap psychique: les enjeux d'une définition en droit social' [A legal approach to psychic disability: issues surrounding a definition in social law], ALTER, European Journal of Disability Research 6 (2012) 255-266; Mabbett, 'Some Are More Equal than Others', supra note 10, pp. 215-233; S. Fredman, 'Does Disability Equality Challenge the Existing Anti-Discrimination Paradigm?', in: A. Lawson and C. Gooding (eds.), Disability Rights in Europe (Oxford: Hart, 2005) pp. 199-219. 
impact on the enforcement of legislation protecting and promoting the rights of persons with disabilities. ${ }^{14}$ In addition, a prescriptive definition is necessary to develop consistent public policies. ${ }^{15}$ Even those, such as Woodhams and Corby ${ }_{16}^{16}$ who advocated for a radical approach that bypasses the requirement for a definition, seem to implicitly recognise that the understanding of disability directly affects the way in which people with disabilities are regarded and treated by state agencies and other bodies.

Against this background, this article discusses which definition of disability has emerged within the EU non-discrimination framework. It attempts to illustrate the shift from a medical model of disability to a holistic social one. ${ }^{17}$ It also examines the efforts to better distinguish the concept of sickness from that of disability, which emerge in the most recent decisions adopted by the CJEU. It also examines the role of the CRPD in the interpretation of the Court. Overall, building on the most recent scholarship, ${ }^{18}$ this article argues that the adoption of a broad notion of disability by the CJEU might correspond to a progressive narrowing of the concept of sickness. This, on the one hand, might clarify the scope of EU non-discrimination legislation, but, on the other hand, it may jeopardize the internal coherence of EU disability law.

Further to this introduction, this article is structured as follows. Before addressing in a detailed fashion the CJEU relevant decisions, Section 2 briefly discusses the conceptualization of disability within the medical and social models. This section is intended to give the reader the necessary background to fully appreciate the relevant case law. Section 3 briefly sketches out the EU legal framework on disability. It is divided into two subsections, the first of which briefly recalls the evolution of EU disability policy, while the second one considers the legal sources of EU disability non-discrimination legislation. Section 4 provides a succinct overview of the role of sickness in EU health and safety at work legislation, which is exclusively focused on preventing

14 M. Oliver and C. Barnes, The New Politics of Disablement (Basingstoke: Palgrave Macmillan, 2012) p. 14 .

15 Mabbett, 'Some are More Equal than Others', supra note 10.

16 C. Woodhams and S. Corby, 'Defining Disability in Theory and Practice: A Critique of the British Disability Discrimination Act 1995', Journal of Social Policy 32(2) (2003) 159-78.

17 See infra Section 2.

18 Inter alia, A. Venchiarutti, 'Sistemi multilivello delle fonti e divieto di discriminazione per disabilità in ambito europeo', La nuova giurisprudenza civile commentata 9 (2014) 409-419. See also C. O’Brien, 'Driving Down Disability Equality? Case C-356/12 Wolfgang Glatzel v. Freistaat Bayern, Judgment of 2 May 2014', Maastricht Journal of European and Comparative Law 21(4) (2014) 723-738; M. Bell, 'Sickness Absence and the Court of Justice: Examining the Role of Fundamental Rights in EU Employment Law', European Law Journal 21 (2015) 641-656. 
occupational causes of ill-health. The purpose of both Sections 3 and 4 is to give the reader a brief account of the legal framework in which the CJEU's case law fits. Sections 5 and 6 focus on the analysis of the Court's judgments in a chronological fashion. While Section 5 addresses case law preceding the ratification of the CRPD, Section 6 centres on more recent decisions and highlights the influence of the ratification of the CRPD by the EU on CJEU case law referring to disability and sickness. Section 7 concludes.

2

\section{Conceptualizing Disability: The Medical Model, the Social Model and Their Influence on Disability Law}

In searching for a clear and prescriptive definition of disability, legal scholars acknowledge that disability itself is 'a reflection of the zeitgeist of a particular time or era, ${ }^{\prime 19}$ and is an evolving concept. Originally and until approximately the 1980s, a 'medical' perspective was dominant. Disability was conceived as an individual deficit deriving from 'a disease, trauma or health condition that impairs or disrupts physiological or cognitive functioning. ${ }^{20}$ The 'medical model' focused on the actual health condition of the single person and on the treatments that could be provided to 'repair' or alleviate the impairment. It conceptualized disability as a negative condition, and identified disability with an individual impairment completely independent from any other external or environmental element. As a consequence, society was split into two distinct social groups: one formed by disabled people, passive beneficiaries of rehabilitation policies, and the other constituted by the 'able bodied citizens', who were providing charitable interventions for the former. This particular categorization stemming from the medical model inevitably led to a form of 'paternalism, ${ }^{21}$ that had informed for many years national and international disability policies. ${ }^{22}$

19 C.E. Drum, 'Models and Approaches to Disability', in: C.E. Drum, G.L. Krahn and, H. Bersani Jr. (eds.), Disability and Public Health, American Public Health Association/ American Association on Intellectual and Developmental Disabilities (Washington, DC: ALPhA Press, 2009) 27-44, p. 27.

20 Drum, ibid., p. 28.

21 V. Perjul, 'Impairment, Discrimination, and the Legal Construction of Disability in the European Union and the United States', Cornell International Law Journal 44 (2011) 279-348, p. 290.

22 F. Seatzu, 'La Convenzione delle Nazioni Unite sui Diritti delle Persone Disabili: i Principi Fondamentali', Diritti umani e diritto internazionale 3 (2008) 535-559, p. 535. 
In the 1960s, however, scholars and disability activists ${ }^{23}$ began to heavily criticize the 'medical model', elaborating a new so-called 'social model of disability'. This novel conceptualization of disability was first put forward by the Union of the Physically Impaired against Segregation (UPIAS) in $1976,{ }^{24}$ but the term 'social model' was initially used by Mike Oliver in his seminal contribution to the volume The Handicapped Person: A New Perspective for Social Workers. ${ }^{25}$ Without exploring the complex literature on the 'social model', it suffices to point out that the main feature of such a theory is the conception of disability as societal creation. ${ }^{26}$ In this model, disability is viewed as the consequence of environmental barriers. While the impairment is the functional limitation within the individual, disability is 'the loss or limitation of opportunities to take part in the normal life of the community on an equal level with others due to physical and social barriers.' ${ }^{27}$ The medical model suggested that disability is the direct consequence of bodily pathology. By contrast, the social model affirms that disability is the result of the interaction between impairments and various barriers. Hence, social and economic structures create disability and are responsible for the exclusion of people with disabilities. ${ }^{28}$ The theoretical reflection on the social model is still evolving.

23 At first, academic interest in disability issues arose during the 1970s in the UK and in the USA. In particular, the UK's first 'disability studies' course was taught at the Open University (OU) in 1975 as an optional module on the ou's Health and Social Studies Degree. In the USA, disability studies were pioneered by disability advocates and academics in the area of medical sociology. C. Barnes, 'The social model of disability: valuable or irrelevant?', in: N. Watson, A. Roulstone, and C. Thomas (eds.), The Routledge Handbook of Disability Studies (London: Routledge, 2012) pp. 12-29.

24 The UPIAS statement underlined the nature of disability as a social construction: 'In our view, it is society which disables physically impaired people. Disability is something imposed on top of our impairments by the way we are unnecessarily isolated and excluded from full participation in society. Disabled people are therefore an oppressed group in society'. The quotation is reported in D. Anastasiou and J. Kaufmann, 'The Social Model of Disability: Dichotomy between Impairment and Disability', Journal of Medicine and Philosophy 38 (2013) 441-459, p. 442.

25 J. Campling, The Handicapped Person: A New Perspective for Social Workers (London: RADAR, 1981).

26 M. Oliver, Understanding Disability: From Theory to Practice (Basingstoke: Macmillan, 1996), p. 35 .

27 C. Barnes, Disabled People in Britain and Discrimination (London: Hurst and Co., 1991).

28 C. Barnes and G. Mercer, Exploring Disability, 2nd edn. (Cambridge: Polity Press, 2010) pp. 29, 35 . 
Different theorisations of the social model itself have been developed, ${ }^{29}$ but a rich and multifaceted critical movement which advocates the inadequacy of the social model is also emerging. ${ }^{30}$

Despite being criticised in more recent years, the social model has undoubtedly been the dominant paradigm in understanding disability and has displayed an enormous influence in the development of the disability agenda at both the national and international levels. ${ }^{31}$ In this short piece of research we are unable to give a full account of national disability law, instead limiting ourselves to highlight that the expansion of the social model of disability marked a new human rights approach at the international level. A cornerstone of this expansion was the adoption of the UN Convention on the Rights of Persons with Disabilities (CR PD or simply 'the Convention'), on 13 December 2006. ${ }^{32}$ It is widely recognized that the CRPD is the first binding international instrument on disability. It is one of the most ground-breaking pieces of legislation in the field of human rights, since it 'seeks to recast disability as a social construction and articulates protections in specific application to their human rights enjoy-

29 There are several 'social models' of disability that are variants of the primary social model: the legal rights model, the minority group model and the affirmation model of disability. There are also a number of models of disability that take elements of the medical and the social models and integrate them: two significant examples are the 'Nagi model' and the 'bio-psycho-social model' of disability. For an analysis of the different approaches mentioned, see among others. Drum, supra note 19, pp. 27-44.

30 Amongst others see Anastasiou and Kaufmann, supra note 24, pp. 441-459; G. Dewsbury, K. Clarke, D. Randall, M. Rouncefield and I. Sommerville, "The anti-social model of disability', Disability \& Society 19(2) (2004) 145-158.

31 As noted by Kayness and French, the primary influence in politics came from the more 'populist' conceptualisation of the social model and from the radical social constructionist view of disability, rather than from its contemporary expression as a critical theory of disability. See R. Kayness, P. French, 'Out of darkness into light? Introducing the Convention of Persons with Disabilities', Human Rights Law Review (2008) 1-34.

32 The Convention was opened for signature on 30 March 2007 and entered into force on 3 May 2008, as did its Optional Protocol. The CRPD text, along with its drafting history, resolutions, and updated list of signatories and States Parties, is available at http://www .un.org/disabilities/. On the Convention, see among others A. Hendricks, 'UN Convention on the Rights of Persons with Disabilities', European Journal of Health Law 14 (2007) 273-298; Seatzu, supra note 22, pp. 535-559; S. Marchisio,V. Della Fina, and R. Cera, La Convenzione delle Nazioni Unite sui Diritti delle Persone con Disabilità: Commentario (Rome: Aracne, 2010) p. XIII. 
ment' in line with the 'social model. ${ }^{33}$ The Convention does not create new rights for disabled persons; rather, it elaborates and clarifies existing human rights within the disability context, ${ }^{34}$ taking into account the social model of disability. The CRPD does not contain a definition of disability, nor of people with disabilities. Article 2, devoted to definitions, does not mention disability. This is the result of a compromise among different conflicting positions that emerged during the negotiations surrounding the Convention. ${ }^{35}$ In the final text, the idea that disability is a flexible and evolving concept, not suitable to be constrained into a strict definition, prevailed. Nonetheless, the CRPD provides a sort of open-ended conceptualization in Article $1,{ }^{36}$ which affirms the purposes of the Convention. Article 1 states that: 'Persons with disabilities include those who have long-term physical, mental, intellectual or sensory impairments which in interaction with various barriers may hinder their full and effective participation in society on an equal basis with others'.

This 'non-definition' of disability is underpinned by the social model and currently provides the minimum grounds for protection to be fulfilled by national legislation, and the necessary starting point for any investigation into the definition of disability.

33 M.A. Stein and J.E. Lord, 'Future prospects for the United Nations Convention on Disability', in: G. Quinn and O.M. Arnardottir (eds.), The UN Convention on the Rights of Persons with Disabilities: European and Scandinavian Perspectives (Leiden/Boston: Brill Nijhoff, 2009) pp. 33-39.

34 For a critical discussion see F. Mégret, 'The Disabilities Convention: Human Rights of Persons with Disabilities or Disability Rights?', Human Rights Quarterly, (30)2 (2008) 494-516; F. Mégret, 'The disabilities Convention: towards a Holistic Concept of Rights', The International Journal of Human Rights (2008) 261-278.

35 During the negotiations of the CRPD, there was disagreement as to whether to include or not a definition of disability in the text of the Convention. Some negotiators, such as the European Union, suggested not including a precise definition, but prioritizing flexibility, adaptation to change and inclusiveness of the concept. Conversely, others, especially NGOS, considered that a strict definition was necessary to prevent States from evading real commitments. The discussions on the topic took place in particular during the Third (24 May-4 June 2004), Fourth (23 August-3 September 2004) and Seventh (16 January-3 February 2006) Sessions of the Ad Hoc Committee on a Comprehensive and Integral International Convention on the Protection and Promotion of the Rights and Dignity of Persons with Disabilities, established by the General Assembly resolution 56/168 of 19 December 2001, http://www.un.org/esa/socdev/enable/rights/ahcstata2bkgrnd.htm retrieved 14 April 2015.

36 G. Quinn, 'A short guide to the United Nations Convention on the right of persons with disabilities', European Yearbook of Disability Law 1 (2009) 89-114. 


\subsection{The E U Disability Policy in a Nutshell: A Long Journey from the Medical to the Social Model}

Until the early 1990s, the former European Community's approach to disability was firmly underpinned by the medical model. The earliest policy actions aimed to mitigate the social effects of impairments, by carving out separate 'parallel social tracks' for people with disabilities. In other words, European actions were directed towards specific measures 'that provid[ed] income and services apart from the institutions that serv[ed] the non-disabled majority'. ${ }^{37}$ This led to the creation of a sort of 'policy of segregation', which assumed the existence of a gap between the social capabilities of persons with disability and those of 'able' citizens. ${ }^{38}$ Between 1974 and 1996, the initiatives that were taken with regard to disability were primarily non-binding (soft law), or took the form of action programmes, providing for exchanges of information. ${ }^{39}$ In the 1980 s, the end of the first EC action programme and the influence of the United Nations disability policy ${ }^{40}$ provided opportunities to broaden the EC agenda beyond the initial and decidedly narrow scope of vocational integration. ${ }^{41}$ The 1986 Recommendation on the Employment of Disabled People in the European Community (86/379/EEC) was based on the principle of 'fair opportunities' for people with disabilities within a European labour market, to be achieved via non-discrimination measures.

37 L. Waddington and M. Diller, 'Tensions and Coherence in Disability Policy: The Uneasy Relationship Between Social Welfare and Civil Rights Models of Disability in American, European and International Employment Law', in: M. Breslin and S. Yee (eds.), Disability Rights Law and Policy (Ardsley, NY: Transnational Publishers, 2002) pp. 241-244.

38 Perjul, supra note 21, p. 290.

39 Initial Community Action Programme for the Vocational Rehabilitation of Handicapped Persons (1974-1979), Council Resolution of 24 July 1974, [1974] OJ C 80/30; First Community Action Programme on the Social Integration of Handicapped People (19831988), 21 December 1981, [1981] oJ C 347/1; HELIos I Community Action Programme for Disabled People (1988-1991), 23 April 1988, [1988] OJ L 104/38; Helios II Community Action Programme to assist Disabled People (1993-1996), Council Decision 93/136/EEC of 25 February 1993, [1993] OJ L 56/30.

40 See the Declaration on the Rights of Mentally Retarded Persons, General Assembly resolution n. 2865 of 20 December 1971, the Declaration on the Rights of Disabled Persons n. 3447 of 9 December 1975, and the International Year of Disabled Persons (1981), General Assembly resolution n. 31/123 of 16 December 1976.

41 See for example the European Parliament Resolution of 11 March 1981, [1981] OJ C 77/21. 
As mentioned above, the '1996 European Community Disability Strategy' represents a true turning point. The 1996 Strategy shows a clear change of direction towards the social model. After the entry into force of the Amsterdam Treaty, in 1999, the disability agenda gained momentum. As a result of an extensive campaign by disability NGOs, the Treaty enabled the Community institutions to take appropriate actions to combat disability discrimination. The enactment of the Employment Equality Directive, which is one of the second generation of equality directives, marked the first legislative intervention to promote the rights of people with disabilities. In the same year, the EU Charter of Fundamental Rights of the European Union was proclaimed. Significantly, the Charter contains different provisions related to disability, the most important of which are Articles 21 and 26.

In 2003, the Commission adopted a new multi-annual action plan on disability running until 2010,42 which was then followed by the European Disability Strategy 2010-2020 (the 'EDS 2010-2020' or simply the 'Strategy'). ${ }^{43}$ The EDS 2010-2020, adopted in November 2010, enunciates the current policy framework, attempts to mainstream disability in all EU policy fields and ensures that people with disabilities enjoy their full rights. While the previous policy programmes had (mainly, whilst not exclusively) a strong focus on employment and accessibility in relation to transportation and built environment, the current Strategy adopts a wider approach and is articulated in eight interconnected key areas of action: accessibility, participation, equality, employment, education and training, social protection, health and external action. The structure and content of the EDS 2010-2020 have been greatly influenced by the EU negotiation and accession to the CRPD, which has marked a definite step forward in the development of a comprehensive EU disability policy, and in the definite abandonment of a pure 'welfare' approach. Indeed, the CRPD itself has become integral part of EU law, ${ }^{44}$ and due to its sub-constitutional status, ${ }^{45}$ now represents the benchmark of the current EU disability policy.

\subsection{Disability as a Ground on Which Discrimination Is Prohibited}

In the EU constitutional framework the principle of non-discrimination and equality is firmly embedded in the Treaties. Article 2 TEU, which states the

\footnotetext{
42 Commission Communication of 30 October 2003, Equal opportunities for people with disabilities: a European Action Plan, сом (2003) 650 final.

43 Commission Communication of 15 November 2010, European Disability Strategy 20102020: A Renewed Commitment to a Barrier-Free Europe, SEC (2010) 1324 final.

44 Ex multis, Case C-239/o3 Etang de Berre [2004] ECR I-07357, para 25. See infra Section 6.

45 See infra Section 5 .
} 
values upon which the Union is founded, includes inter alia, the principle of equality. It also affirms that " $\mathrm{t}$ ] hese values are common to the Member States in a society in which pluralism, non-discrimination, tolerance, justice, solidarity and equality between women and men prevail. Article 3 TEU states that the EU 'shall combat social exclusion and discrimination'. Article 9 TEU mandates the EU institutions to afford all citizens equal attention, and Article $21 \mathrm{TEU}$ sets forth the requirement that the EU be guided by the principle of equality in EU external action. Although these articles do not create any legal rights, their prominent position in the TEU shows that the $\mathrm{EU}$ is committed to ensuring at least equality of opportunity at the present time, and allows for a more substantive form of protection to develop in the future. ${ }^{46}$ The TFEU contains a horizontal clause on non-discrimination in Article $10 \mathrm{TFEU},{ }^{47}$ and provides the EU with a legal basis for the EU non-discrimination legislation. Article 19 TFEU (former Article $13 \mathrm{EC}$ ) allows the EU to take action to combat discrimination on the named grounds of sex, racial or ethnic origin, religion or belief, disability, age or sexual orientation. Furthermore, Article 20 of the Charter of Fundamental Rights of the European Union provides for equality before the law, while Article 21(1) provides for an all-embracing prohibition on discrimination. Article 21 further states that:

Any discrimination based on any ground such as sex, race, colour, ethnic or social origin, genetic features, language, religion or belief, political or any other opinion, membership of a national minority, property, birth, disability, age or sexual orientation shall be prohibited.

Article 26 of the Charter is also worth citing. ${ }^{48}$ This provision states that ' $[\mathrm{t}]$ he Union recognises and respects the right of persons with disabilities to

46 E. Howard, 'Eu Equality Law: Three Recent Developments', European Law Journal, 17 (2011) 785-803; E. Ellis and P. Watson, EU Anti-Discrimination Law (Oxford: University Press, 2012).

47 Article 10 TFEU reads as follows: '[i]n defining and implementing its policies and activities, the Union shall aim to combat discrimination based on sex, racial or ethnic origin, religion or belief, disability, age or sexual orientation'.

48 V. Bongiovanni, 'La tutela dei disabili tra Carta di Nizza e Convenzione delle Nazioni Unite', Famiglia e Diritto, 3(2011) 310-320, also available online: http://www.iusme.it/ contributi/04\%20-\%2oVeronica\%2oBongiovanni.pdf, retrived 14 April 2015, M. Olivetti, 'Uguaglianza. Art. 26 Inserimento dei disabili', in: R. Bifulco, M. Cartabia, A. Celotto (eds.), L'Europa dei diritti. Commentario alla Carta dei diritti fondamentali dell'Unione Europea (Bologna: Il Mulino, 2001) pp. 202-209; C. Hanau, 'Handicap', in: Digesto delle Discipline Pubblicistiche, viII (Turin: Utet, 2003) p. 67. 
benefit from measures designed to ensure their independence, social and occupational integration and participation in the life of the community'.49 These measures (i.e. measures to which Article 26 refers) may concern education, vocational training, ergonomics, accessibility, mobility, means of transport and housing (point 26 of the Community Charter on the Fundamental Social Rights of Workers of 1989), ${ }^{50}$ as well as access to cultural and leisure activities. ${ }^{51}$

Having regard to secondary legislation, former Article 13 EC (i.e., Article 19 TFEU) has been the legal basis for a second generation of equality directives (the so-called 'Article 13 Directives'), which build upon the experience gained in the legislation to combat gender and other forms of discrimination at the $\mathrm{EU}$ level..$^{52}$ Among the non-discrimination instruments, the most relevant in this context and for the purpose of the subsequent analysis, is the already mentioned Employment Equality Directive. As provided for in Article 1, the purpose of this Directive is

to lay down a general framework for combating discrimination on the grounds of religion or belief, disability, age or sexual orientation as regards employment and occupation, with a view to putting into effect in the Member States the principle of equal treatment.

49 The text of the Charter of Fundamental Rights of the European Union is available online, http://www.europarl.europa.eu/charter/pdf/o4473_en.pdf, retrieved 14 April 2015.

$5^{0}$ The Community Charter of the Fundamental Social Rights of Workers establishes the major principles on which the European labour law model is based and, more generally, addresses the role of work in society. On 9 December 1989, the Member States, with the exception of the United Kingdom, adopted a declaration constituting the Community Charter of the Fundamental Social Rights of Workers. Since 1985, increasing concern had been expressed at all levels with the social consequences of the creation of the Single European Market, and there was a perceived need for the formulation and implementation of a comprehensive social dimension for the 1992 programme.

51 Case C-356/12 Wolfgang Glatzel v. Freistaat Bayern of 22 May 2014, not yet published.

52 These Directives include: Directive 2000/78/EC of 27 November 2000 establishing a general framework for equal treatment in employment and occupation, [2000] OJ L 303/16; Directive $2000 / 43 / \mathrm{EC}$ of 29 June 2000 implementing the principle of equal treatment between persons irrespective of racial or ethnic origin, [2000] OJ L 180/22; Council Directive 2004/113/EC implementing the principle of equal treatment between men and women in the access to and supply of goods and services of 13 December 2004, [2004] OJ L 373; Directive 2006/54/EC of the EP and of the Council of 5 July 2006 on the implementation of the principle of equal opportunities and equal treatment of men and women in matters of employment and occupation (recast), [2006] OJ L 204/23. 
There is a huge amount of literature on the Employment Equality Directive and several CJEU decisions have shaped the meaning and the scope of its provisions. For the purpose of this analysis, it suffices to point out that this directive bans both direct discrimination (differential treatment based on a specific characteristic) and indirect discrimination (any provision, criterion or practice which is apparently neutral, but is liable to adversely affect one or more specific individuals or incite discrimination). Settled CJEU case law states that the principle of non-discrimination requires that comparable situations must not be treated differently, that dissimilar situations must not be treated in the same way, and a different treatment may be justified if it is based on objective considerations and is proportionate to the legitimate objective being pursued. ${ }^{53}$ Harassment, which creates a hostile environment, is also deemed to be a form of discrimination. ${ }^{54}$

The Employment Equality Directive requires Member States to provide for effective judicial remedies, bestow representative associations with locus standi to bring actions on behalf of individuals, embed legal rules on shifting the burden of proof to the respondent where a prima facie case of discrimination is established, and provide for sanctions. Notably, the Employment Equality Directive imposes only minimum requirements, and allows Member States to apply provisions which are more favourable to the protection of equal treatment than those laid down in the Directive.

The Employment Equality Directive has had a significant impact on the level of protection provided to victims of disability discrimination in the EU Member States. Nonetheless, several aspects of the directive remain unclear. The question of discrimination by association, i.e. whether the prohibition of discrimination on grounds of disability should include situations where a person is subjected to disadvantage because of their association with somebody who has a disability, was addressed by the CJEU in Coleman v. Attridge Law. ${ }^{55}$ Nonetheless, whether discrimination on the basis of perceived disability (discrimination because a person is erroneously perceived to have a disability) falls within the ambit of discrimination on the basis of disability which

53 Case C-148/o2 Carlos Garcia Avello v. Etat Belge [2003] ECR I-11613.

54 Article 2, paragraph 3, of the Employment Equality Directive specifies that 'harassment shall be deemed to be a form of discrimination within the meaning of paragraph 1 , when unwanted conduct related to any of the grounds referred to in Article 1 takes place with the purpose or effect of violating the dignity of a person and of creating an intimidating, hostile, degrading, humiliating or offensive environment'.

55 Case C-303/o6 S. Coleman v. Attridge Law and Steve Law [2008] ECR I-5603. The European judges held that the Directive should be interpreted to require the prohibition of associative discrimination of this type, at least in relation to direct discrimination or harassment. 
Member States must prohibit is still unclear. ${ }^{56}$ In addition, the scope of the Directive is strictly limited to employment-related issues, as confirmed by the most recent CJEU case-law. ${ }^{57}$

The European Commission has long been concerned to address the pitfalls of the Directive and to extend the EU's non-discrimination legislation beyond the sphere of employment and occupation, addressing discrimination in the fields of social protection, social advantages, education, and access to and supply of public goods and services. With this in mind, in 2008, the Commission presented a Proposal for a New Equal Treatment Directive. ${ }^{58}$ Without addressing this proposal in detail, it suffices to point out that, in addition to covering sectors other than employment, this proposed Directive would introduce a number of additional provisions to strengthen disability discrimination law, including guidance on the meaning of 'disability' in the same terms as Article 1 of the CRPD, thus addressing the absence of a prescriptive definition. However, this proposed Directive is still subject to an ongoing discussion and negotiation in Council. As yet, it has not been possible to achieve the unanimous agreement of all Member States that is required for the adoption of directives based on Article $19 \mathrm{TFEU}$, meaning the directive is far from being approved. ${ }^{59}$

\section{Disability v. Sickness in the EU: From Discrimination to Prevention and Safety}

Before examining the CJEU case law and in order to clarify the legal framework behind the Court's reasoning, it seems appropriate to sketch out the context in which the notion of sickness has emerged and is currently "regulated". We

56 D. Ferri and A. De Paor, 'Regulating Genetic Discrimination in the European Union: Pushing the EU into Unchartered Territory or Ushering in a New Genomic Era?', European Journal of Law Reform 17(1) (2015).

57 Case C-363/12 Z. v. A Government Department and The Board of management of a community school of 18 March 2014, not yet published.

$5^{8}$ Proposal for a Council Directive on implementing the principle of equal treatment between persons irrespective of religion or belief, disability, age or sexual orientation, сом (2008) 426 def.

59 For a detailed report of Proposal's procedure see http://eur-lex.europa.eu/legal-content/ en/HIS/?uri=CELEX:52008PC0426, retrieved 14 April 2015. See also 'Proposal for a Council Directive on implementing the principle of equal treatment between persons irrespective of religion or belief, disability, age or sexual orientation (2008)', The European Union, Annual Review of European Law and Policy, European Yearbook of Disability Law (2015) 173-175; M. Bell, 'Advancing EU Anti-Discrimination Law: the European Commission's 2008 Proposal for a New Directive', The Equal Rights Review, 3(2009) 7-18. 
will not provide a detailed analysis of $\mathrm{E} U$ health and safety at work legislation, ${ }^{60}$ which has already been exhaustively documented by several commentators. ${ }^{61}$ Nor will we discuss social security coordination. ${ }^{62}$ Rather we will try to highlight how the concept of sickness has emerged in the EU but in a discreet way.

First, this can be seen in how sickness has been regulated by the Eu mainly in the context of its health and safety at work legislation, which has emerged since the beginning of the creation of the Internal Market. ${ }^{63}$ Currently, Article 153(1) TFEU provides the legal basis for legislative acts on occupational health and safety, stating that the Union shall support and complement the activities of the Member States in the 'improvement in particular of the working environment to protect workers' health and safety'. While this provision is oriented towards the protection of workers from risks to their health, i.e., to prevention, it does not deal with the consequences that flow when those risks materialize. The EU has mainly a supporting competence, and does not (and arguably cannot) regulate how illness at work (absence due to sickness) must be managed (as this would likely engage with or necessitate social security coordination). Sickness is not mentioned in the Treaties as a ground of discrimination. Likewise, Article 31 of the Charter of Fundamental Rights of the European Union, which provides that 'every worker has the right to working conditions which respect his or her health, safety and dignity', does not confer additional power upon the EU in this context. In line with this constitutional framework, the most significant piece of secondary legislation in the field of occupational health and safety is the 1989 Framework Directive on the introduction of measures to encourage improvements in the safety and health

6o With Council Regulation 2062/94/EC of 18 July 1994 establishing a European Agency for Safety and Health at Work, [1994] oJ L 216/1, the European Union established a decentralised agency, the European Agency for Safety and Health at Work (EU-OsHA) with the task of collecting, analyzing and disseminating relevant information that can serve the needs of people involved in safety and health at work. Further information available online at https://osha.europa.eu/en, retrieved 14 April 2015.

61 Ex pluribus G. Guerra, 'La strategia europea in materia di sanità: esame del programma pluriennale di azione per la salute 2014-2020', Politiche sanitarie 15(4) (2014) 212-215.

62 S.L. Greer and T. Sokol, 'Rules for Rights: European Law, Health Care and Social Citizenship', European Law Journal 20(1) (2014) 66-87.

63 Further to the evolution of the EU policies on health and safety at work, see B. Valdès de la Vega, 'Occupational health and safety: An Eu perspective', in: E. Ales, Health and Safety at Work. European Comparative Perspective (Alphen aan de Rijn: Kluwer Law International, 2013) pp. 1-27. 
of workers at work. ${ }^{64}$ This 1989 Framework Directive is based on the 'principle of absolute prevention', and aims to eliminate the risk factors for occupational diseases and accidents. It obliges employers to establish means and measures for protecting workers, but does not cover those situations in which the worker experiences/suffers from a health condition. It focuses instead on activities of prevention, information and the training of workers, to avoid risks or manage those risks that cannot be avoided. Beside this Framework Directive, the EU has adopted multiple technical and sector-specific directives, which lay down more rigorous or specific provisions. In this respect, it would appear that EU law is primarily focused on preventing occupational causes of ill-health, while not addressing the right to sick leave and the conditions for exercising that right through the substantive reallocation of financial resources. ${ }^{65}$

The concept of sickness also features within $\mathrm{EU}$ legislation on social security coordination: Regulation (EC) No $883 / 2004^{66}$ as implemented by the Implementing Regulation (EC) No 987/2009. ${ }^{67}$ This regulation coordinates social security systems of the Member States, and establishes a framework for the exportability of social security benefits relating to sickness, maternity, invalidity, old age, accidents at work, occupational disease, unemployment, survivors' benefits, death grants and family benefits, but does not apply to medical or social assistance. In this context however, Eu legislation focuses on the benefit itself, rather than on the purpose of that benefit. In addition, a distinction has been made between sickness benefits, explicitly mentioned in the regulation, and 'disability-related' benefits, not addressed expressis verbis. The latter, as extensively discussed by Lisa Waddington, where they amount to social assistance benefits, 'fall outside the scope of the regulations and cannot, for example, be exported under EU law'.68

64 Directive $89 / 391 /$ EEC of 12 June 1989 on the introduction of measures to encourage improvements in the safety and health of workers at work, [1989] OJ L 183/1.

65 Joined Cases C-350/06 Schultz-Hoff v. Deutsche Rentenversicherung Bund and C-520/06 Stringer v. Her Majesty's Revenue and Customs [2010] ECR I-179.

66 Regulation (EC) No 883/2004 of the European Parliament and of the Council on the coordination of social security, [2004] OJ L 166/1.

67 Regulation (EC) No 987/2009 of the European Parliament and of the Council of 16 September 2009 laying down the procedure for implementing Regulation (EC) No 883/2004 on the coordination of social security systems, [2009] OJ L 284/42.

68 L. Waddington, 'Disability Benefits and Entitlements in European Countries: Mutual Recognition and Exportability of Benefits: A synthesis of evidence provided by ANED country reports and additional sources', University of Leeds and European Human Consultancy: Academic Network of European Disability experts - ANED, December 
It appears from this very succinct overview that $\mathrm{E} U$ health law has adopted a narrow approach, focused on the prevention and minimisation of risk that might lead to sickness or injury rather than the allocation of resources if that event takes place. The subsequent absence of an EU non-discrimination policy on the ground of sickness has resulted in disparities across Member States in the levels of protections provided between apparently similar situations, depending on the qualification of the individual condition as disability or as mere illness. Having regards to social security legislation, Regulation (EC) No 883/2004 aims mainly to coordinate Member States' actions, and envisages the portability (though with limitations) of sickness benefits. However, this specific piece of legislation does not address social assistance benefits, meaning that disability-related benefits which amount to social assistance benefits fall outside the scope of the regulations and cannot, for example, be exported under EU law.

Since the 1990s the EU institutions have recognised the need to base policy on the social model of disability. ${ }^{69}$ Notwithstanding this approach, in its first attempt to define disability in Chacon Navas, ${ }^{70}$ the CJEU counterintuitively embraced the outdated and maligned medical model and its definition of what constitutes a disability.

In this case the claimant, a Spanish employee who had been off work sick for eight months, was dismissed. While the employer acknowledged that the dismissal was 'unlawful' under Spanish law and offered her compensation, the employee argued that the dismissal was 'void' due to the unequal treatment and discrimination she suffered. She claimed that she should be reinstated in her post, returning her to the position she was in before the dismissal took place. Although under Spanish law this type of dismissal should have been plainly conceived as unlawful rather than void (because in Spanish law sickness is not expressly referred to as a prohibited ground of discrimination), the Spanish court decided to stay the proceeding and requested a preliminary ruling from the CJEU.

2010, http://www.disability-europe.net/theme/disability-benefits/reports-benefits-enti tlements, retrieved 14 April 2015.

69 See supra Section 3.

70 Case C-13/05 Sonia Chacón Navas v. Eurest Colectividades SA [2006] ECR I-6467. 
The national court argued that there was a causal link between the concept of sickness and that of disability, and argued that sickness is capable of causing 'defects which disable individuals'. The Spanish judges referred to the definition of disability issued by the International Classification of Functioning, Disability and Health (ICF) ${ }^{71}$ and, on the basis of the ICF definition, asserted that 'disability' is a generic term that includes defects, limitation of activity and restriction of participation in social life. ${ }^{72}$ The referring court took the view

that workers must be protected in a timely manner under the prohibition of discrimination on grounds of disability. Otherwise, the protection intended by the legislature would, in large measure, be nullified, because it would thus be possible to implement uncontrolled discriminatory practices.

The Spanish Court acknowledged that, under Eu law, disability and sickness are two separate concepts. It also acknowledged that EU law does not apply directly to sickness. However, it asked whether the Employment Equality Directive might include within its protective scope a worker who has been dismissed by her employer solely because she is sick, or whether sickness might constitute 'an identifying attribute', that 'should be added to the ones in relation to which Directive 2000/78/EC prohibits discrimination. ${ }^{73}$

In order to reply to the questions referred, the Court attempted to interpret the concept of disability and its applicability to the plaintiff's case. In rendering its judgment, the Court adopted a narrow interpretation of disability, based

71 World Health Organisation, ICIDH 2. International Classification of Impairments, Disabilities and Handicaps, Final Draft (Geneva: wHo, 2001). The World Health Organization has elaborated a series of international classifications on health (the so called wHo Family of International Classifications) with the purpose of providing a consensual framework and a common language for governments, providers and consumers in the field. Among these classifications, the International Classification of Functioning, Disability and Health (ICF) establishes a standard language and conceptual basis for the definition and measurement of disability. The ICF recognizes the role of both environmental factors and health conditions in the creation of disability. It is therefore based on the 'bio-psycho-social' model of disability, which integrates the two major models of disability, the medical and the social model. Definitions and categories in the ICF are worded in neutral language: disability and functioning are understood as 'umbrella terms' denoting the positive and negative aspects of functioning from a biological, individual and social perspective.

72 Para. 22, C-13/05, supra note 70.

73 Paras. 21-25, C-13/05, ibid. 
on the medical model, ${ }^{74}$ and consequently clearly distinguished the concept of sickness from that of disability: 75 'the concept of 'disability' must be understood as referring to a limitation which results in particular from physical, mental or psychological impairments and which hinders the participation of the person concerned in professional life. ${ }^{76}$

As noted by Waddington, according to the CJEU the cause of the disadvantage is the individual 'impairment', irrespective of the role played by environmental barriers. Furthermore, differentiating the facts of the case from Mangold, ${ }^{77}$ the Court gave a similarly very narrow interpretation of the scope of the Directive. ${ }^{78}$ It clarified that, although fundamental rights, which form an integral part of the general principles of $\mathrm{EU}$ law, include a general principle of non-discrimination, 'it does not follow from this that the scope of Directive $2000 / 78$ should be extended by analogy beyond the discrimination based on the grounds listed exhaustively in Article 1 thereof. ${ }^{79}$

The Court followed the Opinion of Advocate General (AG) Geelhoeld, who provided a lengthy and detailed interpretation of former Article 13 EC (i.e., Article 19 TFEU) in connection with the Employment Equality Directive. The AG, referring to the evolution and wording of former Article 13 EC, mentioned that the list of prohibited grounds for discrimination is exhaustive and the scope of the directive needs to be interpreted strictly. According to the AG, the Court is bound to respect the choices made by the EU legislature 'with regard to the definition of the prohibition of discrimination and the substantive and personal delineation of that prohibition and must not stretch them'. In line with this reasoning, the Court reaffirmed that the wording of both the Treaty and the directive demonstrated that the EU legislators, by selecting the word 'disability', must be taken to have intended that 'sickness' has a different meaning. ${ }^{80}$ Ultimately, the Court argued that there is nothing in the Employment Equality Directive to suggest that workers who develop any type

L. Waddington, 'Equal to the Task? Re-Examining Eu Equality Law in Light of the United Nations Convention on the Rights of Persons with Disabilities', European Yearbook of Disability Law 4(2013) 169-200. Grand Chamber of 11 July 2006', Common Market Law Review 44(2) (2007) 487-499.

76 Para. 43 C-13/o5, supra note 70.

77 Case C-144/04 Werner Mangold v. Rüdiger Helm, SA [2005] ECR I-9981.

78 F. Evangelista, 'Malattia e handicap, distinte le tutele Ue', Diritto e giustizia, 34 (2006) 100-101; G. Giappichelli, 'La Corte di Giustizia si pronuncia sulla nozione di handicap: un freno alla vis espansiva del diritto antidiscriminatorio?', Riv. it. dir. lav. 4 (2007) 758-775. Para. 56, Case C-13/05, C-13/05, supra note 70.

8 o Para. 44 , ibid. 
of sickness will fall within the purview of the protections granted to those discriminated against based on a personal disability.

In Chacon Navas, the Court established an uncomfortable and potentially dangerous precedent. Not only does it see the Court embrace the medical model, but the Court makes no distinction between long-term or chronic diseases and short-term illnesses. ${ }^{81}$ In the reasoning of the Court, a temporary disability (as defined by the Court itself) seems to fall within the scope of the directive, whilst long term sicknesses fall clearly outside it, but this divide marks a blurred line between protection from and vulnerability to adverse treatment. ${ }^{82}$ As noted by Waddington, ${ }^{83}$ the Court was formally correct in stating that sickness, illness and chronic illness are not explicitly mentioned either in the directive or in Article 19 TFEU. However, we submit that this formalistic approach creates a misleading ambiguity given the fact that the Court failed to explain the existence of any such distinction between sickness and disability.

According to Flynn and Quinn, the formal legal arguments employed by the Court obscure other objectives that it has pursued in its judgment. They suggest that the Court opted for a definition of disability that inflicts the lowest financial burden on Member States in giving effect to that same definition. This view is revealing, and most likely 'the issue of costs (and the need not to unduly intrude on the prerogatives of member States) played a role in determining the boundaries of the definition of disability'. ${ }^{84}$

Subsequently, in Coleman, ${ }^{85}$ the Court did not confront either the precedent established in Chacon Navas or the normative definition of disability. It instead substantially broadened the scope ratione personae addressed within the Directive, disregarding the formalistic approach the Court uses in interpreting the grounds. ${ }^{86}$

81 D. Hosking, 'European Developments. A High Bar for Eu Disability Rights. Case C-13/05, Chacón Navas v Eurest Colectividades SA', Industrial Law Journal 36(2) (2007) 228-237.

82 A.M. Lawson, L. Waddington, European Network of Legal Experts in the non-discrimination field, Disability and Non-discrimination Law in the European Union. An Analysis of Disability Discrimination Law within and beyond the Employment Field (Luxembourg: Publications Office of the European Union, 2009).

83 Waddington, supra note 75, pp. 487-499.

84 G. Quinn and E. Flynn, 'Transatlantic Borrowings: The Past and Future of EU Non discrimination Law and Policy on the Ground of Disability', American Journal of Comparative Law 6o(2012) 23-48.

85 Case C-303/o6, supra note 55.

86 L. Waddington, 'Case C-303/o6, S. Coleman v. Attridge Law and Steve Law, Judgment of the Grand Chamber of the Court of Justice of 17 July 2008', Common Market Law Review $46(2)$ (2009) 665-681. With reference to the implications of Coleman on the topic of 
In Coleman, the reference to the CJEU was made in the course of proceedings between Ms Coleman, and Attridge Law, a firm of solicitors. Ms. Coleman claimed she had been dismissed from her employment and treated less favourably than her fellow employees due to her ancillary role as a primary care-giver for her disabled son in her private life. The referring court asked, in essence, whether the Employment Equality Directive must be interpreted as prohibiting direct, first order discrimination on grounds of disability in respect of an employee who is himself disabled, or whether the principle of equal treatment and the prohibition of direct discrimination applies to second order discrimination. Second order discrimination arises where an employee is not himself disabled but is treated less favourably by reason of the disability of his child, for whom he or she is the primary provider of the care required by virtue of the child's condition, as in Coleman.

Following AG Poiares Maduro's Opinion, ${ }^{87}$ the CJEU noted that

the scope of Directive 2000/78 cannot be extended beyond the discrimination based on the grounds listed exhaustively in Article 1 of the directive, with the result that a person who has been dismissed by his employer solely on account of sickness cannot fall within the scope of the general framework established by Directive 2000/78. ${ }^{88}$

The Court again recalled the Chacon Navas verdict's strict definition of disability ${ }^{89}$ Nevertheless, the European judges did not hold that the principle of equal treatment and the scope ratione personae of that directive must

discrimination of association in EU, see C. Karagiorgi, 'The Concept of Discrimination by Association and its Application in the EU Member States', European Anti-discrimination Law Review (2014) 25-37; D. Venturi, 'Effettività della Tutela Comunitaria contro la Discriminazione Diretta Fondata sull'Handicap ed Estensione dell'Ambito Soggettivo della Tutela: il Caso Coleman', Diritto delle relazioni industriali, 3(2008) 849-854.

87 In his Opinion of 31 January 2008, Advocate General Maduro highlighted that the Directive was adopted under former Article $13 \mathrm{EC}$ and must be interpreted in light of the objectives of that Article. He referred to equality, human dignity and personal autonomy as underlying values. He stated that directly targeting someone who is disabled is one way of discriminating against him, but it is not the only way. He noted that 'the person who is the immediate victim of discrimination not only experiences a wrong himself, but also becomes the means through which the dignity of the person belonging to a suspect classification is undermined.' He stated that a 'robust conception of equality entails that these subtler forms of discrimination should also be caught by anti-discrimination legislation'.

88 Case C-303/o6, para. 46, supra note 55 .

$89 \quad$ Ibid., paras. 45 and 46. 
be interpreted strictly with regard to those grounds, and recognised that discrimination by association or second order discrimination is covered by the directive.

Despite the criticism, the narrow, medical model-oriented concept of disability elaborated in Chacon Navas remained intact in the EU system. This was to be altered, however, with the ratification of the CRPD, which was completed on 23 December 2010.

\section{A New Perspective: The Impact of the Ratification of the CRPD on the EU Definition of Disability}

After the ratification of the CRPD, the CJEU abandoned the outdated medical model and overruled Chacon Navas. In a series of seminal rulings concerning the Employment Equality Directive, the Court firmly embraced a wide-ranging definition of disability, in line with Article 1 CRPD and reflective of the social model of disability.

The Court based its decision to deviate from Chacon Navas on the principle of consistent interpretation governing the relationship between international treaty law and EU law. In this respect, it is well known that Article 216(2) TFEU (former Article $300(7)$ EC) simply stipulates that international agreements concluded by the Union are binding upon the institutions and its Member States. In interpreting this provision, the CJEU has played a vital role in elaborating on the legal consequences of the EU's accession to international treaties. Beginning in the early 1970s, international treaties were considered to form 'an integral part of Community law' 90 once they entered into force. As Wessel states, the notion that international law forms an integral part of $\mathrm{EU}$ law seems to be upheld by recent cases such as Intertanko and Kadi, ${ }^{91}$ even if these cases equally make clear that it is Eu law itself that sets the conditions for the validity of international norms within its legal order. ${ }^{92}$ The status of international

90 Case C-181/73 R. \& V. Haegeman v. Belgian State, [1974] ECR 449. In this decision, the Court used the notion of incorporation, according to which provisions of international agreements are not transposed and do not need further validation. They become part of the EU legal order after the conclusion of the agreement, simply by entering into force.

91 Joined cases C-402/05 and C-415/05 Yassin Abdullah Kadi and Al Barakaat International Foundation v. Council of the European Union and Commission of the European Communities [2008] ECR I-6351.

92 R. Wessel, 'Reconsidering the Relationship between International and Eu Law: Towards a Content-Based Approach?', in: E. Cannizzaro, P. Palchetti, and R.A. Wessel (eds.), 
agreements within the hierarchy of sources of law was also considered by the CJEU. The Court has argued that international treaties are situated formally below the provisions of the Treaties. ${ }^{93}$ It derives that, in hierarchical terms, the CRPD is inferior to the provisions of the Treaty on the Functioning of the European Union (and the Treaty on European Union), but superior to secondary EU law. The latter point implies that provisions of EU secondary law must, as far as practicable, be interpreted in a manner that is consistent with those agreements ${ }^{94}$ Namely, the Employment Equality Directive must now be interpreted in light of the CRPD.

The first case in which the Court explicitly referred to the CRPD was Ring and Werge. ${ }^{95}$ Ms Jette Ring and Ms Lone Skouboe Werge were both dismissed after several absences from work caused by their health conditions. The trade union $\mathrm{HK}$, acting on behalf of the two applicants, submitted that both employees were suffering from a disability. It claimed that their employers were required to offer them reduced working hours, by virtue of the obligation to provide accommodation pursuant to Article 5 of Employment Equality Directive. In both main proceedings the employers disputed the contention that the applicants' state of health was covered by the concept of 'disability' within the meaning of the directive. The referring courts thus asked the CJEU if and when a condition caused by a medically diagnosed illness could be covered by the ground of disability. The CJEU was thus called to resolve the uncertainty created by the Chacón Navas case about the borderline difference between disability and sickness.

In its decision, the Court articulated that the Employment Equality Directive must, as far as practicable, be interpreted in a manner consistent with the CRPD. It subsequently emphasised a social model-oriented definition of disability consistent with the Convention. It considered in particular the wording

International Law as Law of the European Union (Leiden: Martinus Nijhoff Publishers, 2011) pp. 7-35.

93 In particular, as regards mixed agreements, the Court has also stated that they 'have the same status of purely Community agreements, in so far as the provisions fall within the scope of Community competence'.

Case C-61/94 Commission v. Germany [1996] ECR I-3989, [52]. F. Casolari, 'Giving Indirect Effect to International Law within the EU Legal Order: The Doctrine of Consistent Interpretation', in: Cannizzaro et al. (eds.), supra note 92, pp. 395-415.

95 Joined cases C-335/11 and C-337/11, HK Danmark acting on behalf of Jette Ring v. Dansk Almennyttigt Boligselskab (C-335/11) and нк Danmark, acting on behalf of Lone Skouboe Werge v. Dansk Arbejdsgiverforening, acting on behalf of Pro Display $A / S$, in liquidation (C-337/11) of 11 April 2013, not yet published. 
of Recital (e) ${ }^{96}$ and Article 1, paragraph $2^{97}$ of the Convention, which recognises that 'sickness can, in some circumstances, constitute a disability' for the purpose of the directive:

if a curable or incurable illness entails a limitation which results in particular from physical, mental or psychological impairments which in interaction with various barriers may hinder the full and effective participation of the person concerned in professional life on an equal basis with other workers, and the limitation is a long-term one, such an illness can be covered by the concept of 'disability' within the meaning of Directive $2000 / 78.98$

The Court distinguished between short-term illnesses, which are not to be regarded as a disability, and long-term impairments which can be caused by sickness and which, when subject to various barriers and exogenous factors, can be regarded as disabilities. ${ }^{99}$

Furthermore, the CJEU has adopted an 'aetiology-neutral' concept of disability, in line with the wHo classifications. ${ }^{100}$ This means that the Employment Equality Directive 'is not intended to cover only disabilities that are congenital or result from accidents, to the exclusion of those caused by illness.' ${ }^{101}$ The Court, on the basis of the ICF and the CRPD, does not draw any explicit or implicit distinction between different health conditions, shifting the focus from the health condition to the functionality of the individual, and to the disability resulting from the interaction with external barriers.

In Ring and Werge, the CJEU openly distanced itself from the position it took in Chacon Navas and interpreted the definition of disability in light of

96 CRPD, Preamble, Recital (e): 'Disability is an evolving concept and that disability results from the interaction between persons with impairments and attitudinal and environmental barriers that hinders their full and effective participation in society on an equal basis with others'.

97 Article 1(2) CRPD is reported in the introduction.

98 Joined cases C-335/11 and C-337/11, para. 41, supra note 95 .

99 L. Waddington, 'HK Danmark (Ring and Skouboe Werge): Interpreting EU Equality Law of the UN Convention on the rights of persons with disabilities', European Antidiscrimination Law Review (2013) 11-23, p. 21.

100 World Health Organization, How to Use the ICF: A Practical Manual for Using the International Classification of Functioning, Disability and Health (ICF). Exposure Draft for Comment (Geneva: WHO, 2013).

101 Joined cases C-335/11 and C-337/11, para. 40, supra note 95. 
the CRPD. ${ }^{102}$ Subsequently, the CJEU has had several opportunities to refine both the definitions of disability and the effects of the CRPD on EU law. ${ }^{103}$ In Commission v Italy ${ }^{104}$ the CJEU confirmed that, while it is true that the concept of 'disability' is not directly defined in the Employment Equality Directive, it should be interpreted in light of the CRPD. Similarly, in Z. v. A Government Department and the Board of management of a community school, the Court referred to Article 1 CRPD and again firmly embraced the social model of disability. This case concerned surrogacy, and the Court discussed whether and how this practice might be covered by the current legal framework on maternity leave. In particular, the CJEU was confronted with the question of whether a mother who did not give birth to her own child, born via a surrogate, has a right to maternity leave under EU law. In this context, the CJEU clarified that, even though infertility could be categorized as a disability under the CRPD, the Employment Equality Directive does not apply to women unable to become or carry out a pregnancy. The Court relied on the limited scope of the directive ratione materiae, as the directive only targets disabilities that make a worker's involvement in professional life more burdensome, which is not the case for medical conditions that prevent women from getting pregnant. Namely the Court stated that 'the inability to have a child by conventional means does not in itself, in principle, prevent the commissioning mother from having access to, participating in or advancing in employment'. Again, in Glatzel, ${ }^{105}$ the Court recalled its own case law and held that the definition of 'disability' must be understood 'as long-term physical, mental or psychological impairments

102 Venchiarutti, supra note 18, p. 416.

103 In C-363/12 Z. v. A Government, paras. 84-90, supra note 57, and in C-356/12 Glatzel, paras. 68-69, supra note 51 , the Court pointed out that in so far as the obligations imposed by that Convention are addressed to Contracting Parties, that international agreement is 'programmatic'. Consequently, since the provisions of the CRPD are subject, in their implementation or effects, to the adoption of subsequent measures which are the responsibility of the Contracting Parties, they therefore do not have direct effect in European Union law. It follows that the validity of Directive 2000/78 cannot be assessed in the light of the UN Convention, but that directive must, as far as possible, be interpreted in a manner that is consistent with that Convention.

104 Case C-312/11 Commission v. Italy of 4 July 2013, not yet published. The case originated from an action for failure to fulfil $\mathrm{EU}$ obligations brought by the Commission against Italy. The Commission affirmed that Italy did not correctly transpose Directive 2000/78 into its national law, and, in particular, it did not ensure, in breach of the Directive, that reasonable accommodation in the workplace is to apply to all persons with disabilities, all employers, and all aspects of the employment relationship.

105 Case C-356/12, supra note 51. 
which in interaction with various barriers may hinder the full and effective participation of the person concerned in professional life on an equal basis with other workers', although, then, the Court stated that it did not have sufficient information to ascertain whether Mr. Glatzel's impairment constituted a 'disability'.

It is, however, only in Kaltoft ${ }^{106}$ that the Court addressed again the relationship between disability and sickness. The facts concerned the dismissal of Mr. Karsten Kaltoft, who worked for 15 years for the Municipality of Billund (Denmark) as a childminder. During his employment, consequent to his recognised obesity, Kaltoft was provided financial assistance to fund fitness and physical training sessions as part of the local authority's health policy, but without successful results. Although the employer disputed that Mr. Kaltoft's obesity formed part of the reasons behind his dismissal, the Fag og Arbejde, a workers' union acting on behalf of Mr. Kaltoft, brought proceedings founded upon unlawful discrimination on grounds of disability. The claimant argued in his written observations that the WHO considers obesity to be a chronic and durable illness. ${ }^{107}$ Furthermore, he pointed out that obesity has been considered to be a disability under the law of the United States of America. Obesity can, in fact, entail physical limitations that create obstacles to the full and effective participation in professional life, either because of reduced mobility or because of pathologies or symptoms that result from it, and it can equally entail limitations on the employment market by reason of prejudice on the basis of physical appearance. ${ }^{108}$ In these circumstances, the referring court asked the CJEU if obesity could be deemed to be a disability within the meaning of the Employment Equality Directive. ${ }^{109}$

106 Case C-354/13 Fag og Arbejde (FOA), acting on behalf of Karsten Kaltoft, v. Kommunernes Landsforening $(K L)$, acting on behalf of the Municipality of Billund of 18 December 2014, not yet published.

107 The wHO ranks obesity into three classes by reference to the BMI. Persons with a BMI of 30.00 to 34.99 are Obese class I, persons with a BMI of 35.00 to 39.99 are Obese class II, and persons with а BMI in excess of 40.00 are Obese class III, which is sometimes referred to as severe, extreme or morbid obesity.

108 Case C-354/13, para. 52, supra note 106.

109 Although it is not relevant for the purpose of this article, it is worth highlighting that by its first question, the referring court essentially asked whether Eu law must be interpreted as laying down a general principle of non-discrimination on grounds of obesity as such as regards employment and occupation. After a brief analysis of the EU law and case law (with reference in particular to Chacon Navas) on the topic (paras. 31-40), the Court finally opted out for a negative solution. 
Both the Opinion of the AG and the judgment of the Court recognized that, even if obesity does not in itself constitute a disability within the meaning of Directive 2000/78/EC, nonetheless

in the event that, under given circumstances, the obesity of the worker concerned entails a limitation which results in particular from physical, mental or psychological impairments that in interaction with various barriers may hinder the full and effective participation of that person in professional life on an equal basis with other workers, and the limitation is a long-term one, obesity can be covered by the concept of 'disability' within the meaning of Directive 2000/78. ${ }^{110}$

The CJEU did not deal with this issue directly, other than to provide these criteria. Instead, it returned the matter to the national court to determine whether, in the main proceedings, the above conditions are met. ${ }^{111}$

The Court's judgment illustrates a perfect juxtaposition between the concepts of illness and of obesity and, because of this, the Court was able to recall the conclusions of Ring and Werge. Notably the Court distanced itself somewhat from AG Jääskinen's opinion, blurring the distinction between sickness and disability. First, the AG explicitly compared obesity to an illness, recalling the wHO classification. Conversely, the Court in referring to obesity never used the words illness or sickness, even if the comparison between illness and obesity rests in the background. The Court seemed to move much more cautiously in defining obesity, merely stating that it entails a general 'limitation' to exercising an activity. In addition, the AG succumbed to the temptation to partially adopt a medical approach, proposing that only severe obesity (according to the wHo classification) could amount to a disability and so fall within the purview of the Employment Equality Directive, provided that all the requisites set out in Ring and Werge are met. By contrast, the final judgment did not mention any distinction between obesity 'classes', leaving to the national courts (and legislation) such distinction. The Court therefore demonstrates a

110 Case C-354/13, para. 59, supra note 106.

111 For a critical comment on the possible consequences of Kaltoft in EU disability discrimination law see I. Solanke, 'Kaltoft — a step (in the wrong direction?) towards protection from weight discrimination under Eu law', Eutopia law 2014, 22 December 2014, http:// eutopialaw.com/2014/12/22/kaltoft-a-step-in-the-wrong-direction-towards-protectionfrom-weight-discrimination-under-eu-law/, retrieved 14 April 2015. 
particular reticence in addressing such a topical issue, ${ }^{112}$ acknowledging that the implications of recognising obesity as a disability could have a large impact on the labour market and, recalling Flynn and Quinn's arguments, on the costs to be borne by the Member States, especially those where obesity is an increasing phenomenon. ${ }^{113}$

Lastly, although the Eu has neither signed nor ratified the Optional Protocol to the CRPD, it might be argued that the CJEU was deeply influenced by the jurisprudence of the UN Committee on the Rights of Persons with Disability, which provides an authentic interpretation of the Convention. Just one month before Kaltoft, the Committee had the chance to offer its own interpretation of the concept of disability contrasting it to that of sickness in Ms. s.c. v Brazil. ${ }^{114}$ The Committee specified that the (non) definition of disability in Article 1 CRPD is not to be interpreted strictly, but could potentially cover a wide range of situations not explicitly listed in the Convention. ${ }^{115}$ In particular, the Committee stated

112 During the last few years, the EU has demonstrated a specific sensitivity on obesity issues. On 30 May 2007, the EU Commission established a coherent and comprehensive Community Strategy to address the issues of being overweight and of obesity, by adopting the White Paper on 'A Strategy on Nutrition, Overweight, and Obesity-related health issues', focusing on action that can be taken at local, regional, national and European levels to reduce the risks associated with poor nutrition and limited physical exercise. On the topic, see, amongst others, B. Buchner, 'Nutrition, Obesity and Eu Health Policy', European Health Law Journal, 18(8) (2011) 1-8; A. Faeh, 'Obesity in Europe: The Strategy of the European Union from a Public Health Law Perspective', European Journal of Health Law 19(18) (2012) 69-86; C. MacMaoláin, 'Food Information Regulation: Failing to address ongoing concerns about obesity', Irish Journal of European Law 17(1) (2014) 77-86.

113 For instance, with reference to the possible impact of Kaltoft in the UK, see M. Butler, 'Obesity as a Disability: The Implications or Non-Implications of Kaltoft', 20(3) (2014) Web Journal of Current Legal Issues, http://webjcli.org/article/view/358/466, retrieved 14 April 2015; K. Ferris and J. Marson, 'Does Disability Begin at 40? Karsten Kaltoft v Kommunernes Landsforening (KL), acting on behalf of the Municipality of Billund (Advocate General's Opinion) [2014]', 20(3) Web Journal of Current Legal Issues (2014), retrieved 14 April 2015, http://webjcli.org/article/view/373.

114 S.c. v. Brazil, CR PD /C/12/D/10/2013, adopted during the 12th session of the Committee, from 15 September to 3 October 2014. The Committee's decision was published on 13 November 2014, while the Kaltoft case was decided on 18 December 2014. The Committee's decision is available online: http://tbinternet.ohchrorg/_layouts/treatybodyexternal/Download. aspx?symbolno=CRPD-C-12-D-10-2013\&Lang=en, retrieved 14 April 2015.

115 The Committee specified that, under Article 1 of the Convention, 'persons with disabilities include, but are not limited to [emphasis added], those who have long-term physical, 
the difference between illness and disability is a difference of degree and not a difference of kind. A health impairment which initially is conceived of as illness can develop into an impairment in the context of disability as a consequence of its duration or its chronicity. A human rights-based model of disability requires the diversity of persons with disabilities to be taken into account. ${ }^{116}$

Although the language used might appear ambiguous, the Committee theorized a potential overlap between the two concepts analysed, identifying in the chronicity or duration of the impairment the mark of distinction between them. Nonetheless, it does not clarify any precise standard to be used to distinguish the two notions. In particular, the 'duration' is left quite undefined, although it might be argued that the Committee referred to long-term conditions. Even if in Kaltoft there is not any explicit mention of the Committee's decision, at first sight the Court's approach appears in line with the broad interpretation provided by the Committee.

\section{Conclusions}

Absent an EU-wide legislative definition of the ground of disability, the Court of Justice of the European Union has sought to fill this void in a cautious manner. The ratification of the CRPD, in 2010, has led to a clear departure in the jurisprudence of the Court: the European judges openly shifted from the medical model to the social model of disability. The (non)definition provided by the CRPD now represents a landmark for the CJEU, which recognised that a duty arises to adopt a social model of disability under the principle of consistent interpretation, by virtue of the 'sub-constitutional' ranking of international agreements. ${ }^{117}$ However, the CJEU's developments in defining disability within the non-discrimination field are producing spillover effects: disability is used as an 'umbrella-term', encompassing a large variety of different health situations. This has inevitably had the result of implicitly enlarging the scope of the Employment Equality Directive ratione personae. In the most recent case law,

mental, intellectual or sensory impairments which, in interaction with various barriers, may hinder their full and effective participation in society on an equal basis with others'.

116 s.c. v. Brazil, supra note 114, p. 8.

117 Case C-335/05 Ǩízení Letového Provozu čR, s. p. v. Bundesamt für Finanzen [2007] ECR I-4307; Case C-92/71 Interfood GmbH v. Hauptzollamt Hamburg [1972] ECR 231; Case C-363/12 Z. v. A Government, supra note 57; Case C-356/12, Glatzel, supra note 51. 
in particular Kaltoft, a wide social-model oriented notion of disability has filled normative gaps within the $\mathrm{EU}$ directive.

Overall, even though it is not certain what influence the CRPD will have in the future, nor whether and to what extent the decisions of the UN Committee will be adopted in CJEU case law, it remains possible that the Court will continue with the progressive enlargement of the concept of disability started with the Ring and Werge case. The main constraint we envisage relates to the CJEU's role in preserving the internal coherence of the EU legal system: a more pronounced overlap of the two concepts of disability and sickness could have an even greater impact on EU employment law. Some health conditions, such as stress, anxiety and depression, can already be qualified as 'psychosocial disabilities'. They are amongst the leading causes of sickness absence in Europe, ${ }^{118}$ but they are characterized by difficulty of diagnosis and undetermined duration, and have chronic effects that are highly difficult to predict. In similar borderline cases, a broad interpretation of the concept of disability as a ground of discrimination could lead to an enormous amplification of the scope of the Employment Equality Directive ratione personae. However, substantially conflating the categories of sickness and disability in the non-discrimination field could jeopardize the internal coherence of the entire EU system, leading to clashes and different levels of protection provided in regards to sickness and disability in health and social security legislation.

118 According to EUROSTAT, in Europe $14 \%$ of the persons with a work-related health problem experienced stress, depression or anxiety as the main health problem. After musculoskeletal health problems, this mental health issues constitutes the second most frequently reported main work-related health problem. See Eurostat, 'Health and Safety at Work in Europe (1999-2007). A Statistical Portrait', Eurostat Statistical Books (Luxembourg: Publications Office of the European Union, 2010), p. 67. Data do not include France. 